SJ Quinney College of Law, University of Utah Utah Law Digital Commons

Wallace Stegner Center for Land, Resources, and the Environment publications

2020

Beyond the Antiquities Act: Can the BLM Reconcile Energy

Dominance and National Monument Protection?

John C. Ruple

Heather Tanana

Follow this and additional works at: https://dc.law.utah.edu/stegner_pubs

Part of the Environmental Law Commons, and the Natural Resources Law Commons 


\title{
Beyond the Antiquities Act: Can the BLM Reconcile Energy Dominance and National Monument Protection?
}

\author{
Authors: John C. Ruple and Heather Tanana \\ Date: Wntr 2020 \\ From: Natural Resources \& Environment(Vol. 34, Issue 3) \\ Publisher: American Bar Association \\ Document Type: Article \\ Length: 4,643 words
}

Full Text:

Signed into law on June 8, 1906, the Antiquities Act is concise in its charge but broad in effect, authorizing presidents to designate national monuments to protect "objects of historic or scientific interest" on federally owned or controlled land. 54 U.S.C. [section] 320301 (a). Republican and Democratic presidents have used this authority to designate over 150 national monuments across 32 states, the District of Columbia, and various U.S. territories. Many national monuments--including iconic landscapes like the Grand Canyon in Arizona, Zion in Utah, Joshua Tree in California, and Grand Teton in Wyoming--were subsequently elevated to national park status.

Under the Antiquities Act, the president may reserve monument lands from future mineral development or disposal in order to protect monument objects. Id. at [section] 320301(b). But the act includes scant additional management direction, dictating only that archaeological excavations cannot proceed absent a government-issued permit. Until recently, national monuments were managed with an understanding that the balance between competing uses tipped in favor of protecting the objects identified in the proclamation. Standard practice ended under the Trump Administration, when the president issued a series of executive orders promoting development of domestic energy resources. See, e.g., Exec. Order No. 13,783 (Mar. 28, 2017) and Exec. Order No. 13,868 (Apr. 10, 2019). This "energy dominance" agenda conflicts with resource protection, and the collision is playing out at two national monuments in southern Utah--the Grand Staircase-Escalante National Monument (GSENM) and the Bears Ears National Monument (BENM).

\section{Establishing GSENM and BENM}

On September 18, 1996, President Clinton designated 1.7 million acres as the GSENM to protect a "spectacular array" of sensitive scientific, historic, prehistoric, archaeological, paleontological, cultural, and natural resources. Presidential Proclamation No. 6920 (Sept. 18, 1996). The proclamation creating the monument also withdrew monument lands from mineral development and disposal. President Clinton described the GSENM, which was the last place in the continental United States to be mapped, as an unspoiled frontier and a "geologic treasure" teeming with "world class paleontological sites," a place "rich in human history," and containing "an extraordinary number of areas of relict vegetation, many of which have existed since the Pleistocene." Id. Indeed, the GSENM, which is managed by the Bureau of Land Management (BLM), has produced discoveries of over 45 new paleontological species, including 12 new species of dinosaurs.

Two decades later, President Obama used the Antiquities Act to designate the culturally and archaeologically rich BENM in southern Utah. Presidential Proclamation No. 9558 (Dec. 28, 2016). As President Obama explained,

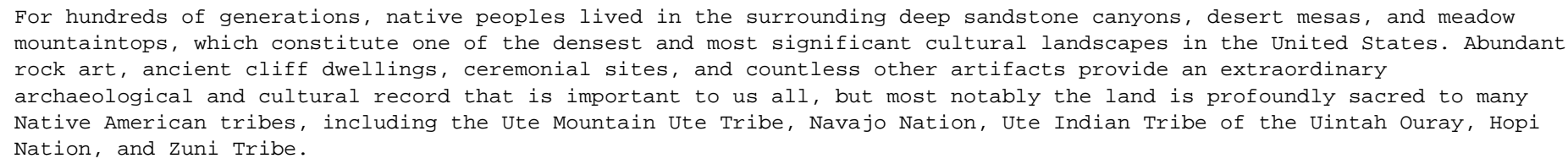

Id. The BENM is collaboratively managed by the BLM and U.S. Forest Service, with the BLM managing most monument lands.

Less than a year after the BENM was set aside, President Trump cut 2 million acres from the two monuments--a reduction that was twice the size of the state of Rhode Island. Presidential Proclamation Nos. 9681 and 9682 (Dec. 4, 2017). President Trump contends that some objects identified in the original proclamations are not worthy of protection, that other objects are adequately protected by other laws, and that the monuments are larger than needed to protect "objects of historic or scientific interest." He too claims to act 
While lawsuits challenging the validity of President Trump's revision proclamations wind slowly through the federal courts, the BLM and U.S. Forest Service must continue managing landscapes that are caught in a legal and policy limbo. Setting ongoing litigation aside, we focus on the lands that "remain" within these two monuments according to the revision proclamations and attempt to define the legal sideboards on management of these lands and the "objects of historic or scientific interest" they contain.

\section{GSENM and BENM Management}

The Antiquities Act contains little direction on how monument lands should be managed, leaving those decisions to the presidential proclamations creating national monuments and the discretion of the agencies that manage them. The original proclamations designating GSENM and BENM both expressly reserved monument lands to protect the objects identified in the proclamations and directed the secretaries of the Interior and Agriculture to manage the two monuments to implement the purposes stated in the proclamations. To guide the agencies in managing monument resources, both original monument proclamations also require resource managers to prepare management plans for the monuments.

While reducing GSENM and BENM by 50 and 85 percent respectively, President Trump left intact the broad outlines for managing what remains of the two monuments. A few specific exceptions aside, his proclamation modifying the BENM does not "change the management of the areas designated and reserved... that remain part of the monument." Proclamation No. 9681 at 58085-86. Similar language applies to the GSENM. See Proclamation No. 9682 at 58094 . Protecting monument resources, in short, remains the goal of both monuments.

The BLM completed a management plan for the GSENM in 1999, but a management plan for the BENM was not completed prior to President Trump's reductions. In January of 2018, federal land managers announced their decision to revise the management plan for the GSENM and to prepare a management plan for the BENM. Seven months later, the agencies released draft management plans and environmental impact statements (EISs) for both monuments. Proposed management plans and Final EISs for the BENM and GSENM followed in July and August of 2019, respectively.

The proposed management plan and Final EIS for the GSENM considers four action alternatives, as well as a no-action alternative that is required under the National Environmental Policy Act (NEPA). The BLM's proposed plan is generally the least protective alternative, changing little from the preferred alternative in the Draft EIS. The proposed plan "emphasize[s] resource use" and "reduce[s] constraints on resource development." U.S. Dept. of the Interior, Grand Staircase-Escalante National Monument and Kanab-Escalante Planning Area Proposed Resource Management Plan and Final Environmental Impact Statement, ES-8 (2019). The GSENM proposed plan, for example, designates fewer right-of-way avoidance and exclusion areas within the monument more than any other alternative and reduces the size of these protected areas to below the level contained in the no action alternative. Id. at ES-22. It would also increase the amount of land open to commercial livestock grazing and aggressive vegetation treatment while minimizing protections for cultural resources, paleontological resources, wildlife habitat, wilderness characteristics, soil and water resources, and visual resources. Id. at ES-11-ES-27.

An increase in impacts flows logically from reduced protections. As the BLM acknowledges, its proposed plan "may increase the potential for adverse effects on resources" because it includes "the least amount of special designations and allocations that would protect or maintain resource values and designate[s] no [Areas of Critical Environmental Concern]." The proposed plan also does not "specif ically manage [any] lands for wilderness characteristics... [and represents the alternative] most likely to increase the potential for management conflicts and associated impacts on lands adjacent to the Planning Area." Id. at ES-9.

The BLM further concedes that the proposed plan poses a heightened potential for impacts on scenic values within the monument; natural soundscapes both within the monument and on adjacent National Park Service lands; suitable Wild and Scenic River corridors within the monument; and both paleontological and soil and water resources that the BLM identifies as "monument objects." Id.

The draft management plan and Final EIS for the BENM similarly proffered the least protective option as the agency preferred alternative. The proposed plan for BENM refines the preferred alternative in the Draft EIS slightly, but it generally remains the least protective action alternative. U.S. Depts. of the Interior and Agriculture, Bears Ears National Monument: Proposed Monument Management Plans and Final Environmental Impact Statement Shash Jaa and Indian Creek Units, ES-6-ES-11 (2019). Impacts to monument resources at BENM, under the agencies' proposed management plan, would overshadow those of the other alternatives. Over 38,000 acres of land with medium to high cultural sensitivity, for example, would be open to right-of-way applications under the proposed plan--the most of any action alternative and an amount identical to the proposed alternative in the Draft EIS. BENM Proposed Plan at ES-6. The proposed plan also contemplates expansion of off-highway vehicle (OHV) trails into the Indian Creek portion of the monument, would eliminate limits on the size of groups that can access the sensitive Cedar Mesa and Comb Ridge areas, and "would not manage inventoried lands with wilderness characteristics specifically to protect wilderness characteristics." Id. at 2-14, 2-18, and 3-48. Lax protections for visual quality "could result in adverse impacts on the scenic quality of the Planning Area and diminish the recreational experience of recreational users who visit the Monument to enjoy its scenic resources and desire a more primitive recreation setting." Id. at 3-48.

\section{Monument Management Requirements Imposed by FLPMA and the Omnibus Public Lands Act of 2009}

While the Antiquities Act provides scant direct protection to national monument lands and the objects these lands contain, additional direction and resource protection are contained in other federal laws that apply to national monument management. 
Both proposed plans and their accompanying EISs give only passing attention to protections of "objects of historic or scientific interest" that are imposed by either the Federal Land Policy and Management Act of 1976 (FLPMA) or the Omnibus Public Lands Act of 2009 and therefore raise the question: Are the proposed plans consistent with statutory direction?

Section 302(a) of FLPMA directs the Secretary of the Interior to "manage the public lands under principles of multiple use and sustained yield... except that where a tract of such public land has been dedicated to specific uses according to any other provisions of law it shall be managed in accordance with such law." 43 U.S.C. [section] 1732(a) (emphasis added). The legislative history of this provision provides scant insight into its origin or congressional intent, though the text appears clear on its face. Broadly speaking, FLPMA modernized and consolidated the BLM's management authority while increasing the emphasis on resource protection. FLPMA also moved the BLM away from a policy of resource disposal toward a policy that, among other things, "protect[s] the quality of scientific, scenic, historical, ecological, environmental, air and atmospheric, water resource, and archeological values; that, where appropriate, will preserve and protect certain public lands in their natural condition." 43 U.S.C. [section] 1701(a)(8).

BLM-managed monuments like the GSENM and BENM are also protected as part of the National Landscape Conservation System (NLCS). Created administratively in 2000 and incorporated into federal law as part of the Omnibus Public Lands Act of 2009, the NLCS was established to "conserve, protect, and restore nationally significant landscapes that have outstanding cultural, ecological, and scientific values for the benefit of current and future generations." 16 U.S.C. [section] 7202(a). BLM managed national monuments are part of the NLCS, and the Secretary of the Interior is specifically directed to manage National Conservation Lands "in a manner that protects the values for which the components of the system were designated." Id. at 7202(c)(2).

BLM's Manual 6220 provides guidance for implementing these statutory charges. Under Manual 6220, the BLM must "[m]anage discretionary uses within Monuments... to ensure the protection of the objects and values for which the Monuments... were designated." BLM Manual 6220 [section] 1.2(C) (2017). Where language contained in a monument proclamation conflicts with FLPMA's multiple use mandate, the more protective proclamation language controls. Id. at [section] 1.6(B)(1). As a result, the BLM's monument planning and implementation level decisions pertaining to the objects for which the monuments were designated must be consistent with monument proclamations.

The BLM Manual also provides guidance specific to transportation planning. "[T]o the greatest extent possible," the BLM should "avoid designating or authorizing use of transportation or utility corridors within Monuments," by designating monuments as "exclusion or avoidance areas," not designating incompatible corridors, and "relocating any existing designated transportation and utility corridors outside the Monument." Id. at [section] 1.6(E)(8). The BLM Manual is equally explicit regarding utility rights-of-way, again requiring that to the greatest extent possible, the BLM "avoid granting new rights-of-way in Monuments," and "consider routing or siting the ROW outside of the Monument." Id. at [section][section] 1.6(E)(2)(b),1.6(E)(7), and 1.6(G) (4)(f).

The direction contained in BLM Manual 6220 is hard to square with the BLM's proposed plans for the GSENM or the BENM. The proposed plan for the GSENM would establish fewer right-of-way avoidance and exclusion areas than any other alternative, including the no action alternative. Overall, the proposed plan for the GSENM "may increase the potential for adverse effects on resources" over any other alternative, including the no-action alternative. The proposed plan is also the "most likely to increase the potential for management conflicts and associated impacts on lands adjacent to the Planning Area." GSENM Proposed Plan at ES-9.

Similarly, the proposed management plan for the BENM would open more culturally sensitive lands to right-of-way application than any other alternative and would threaten a delicate cultural landscape by increasing OHV access, reducing or eliminating group size restrictions in some of the monument's most sensitive areas, foregoing management protections for lands with wilderness characteristics, and opening sensitive lands to right-of-way application.

Interpreting the BLM's Obligations under FLPMA and the NLCS

As previously discussed, FLPMA requires that where a tract of BLM-managed public land "has been dedicated to specific uses according to any other provisions of law it shall be managed in accordance with such law" rather than the BLM's broad multiple use mandate. 43 U.S.C. [section] 1732(a). The interplay between FLPMA's multiple use--sustained yield mandate and provisions of law associated with special designations has received scant judicial attention. Only four cases substantively analyze the BLM's obligations under section 302(a) of FLPMA, and all hold that the BLM must manage national monuments in accordance with the terms of the monument proclamation. See, e.g., Western Watersheds Project v. Abbey, 719 F.3d 1035, 1042 (9th Cir. 2013). Management must therefore, at a minimum, protect the objects identified in the proclamation. Existing case law has not expressly addressed management of National Conservation Lands, though that statutory mandate appears clear on its face. The question that remains is whether the Trump Administration's approach to monument management can be squared with congressional direction.

In 2011, the federal district court in Arizona addressed a challenge to the BLM's management of the Grand Canyon--Parashant and Vermillion Cliffs National Monuments. Plaintiffs contended that the monument management plans allowed vehicle use and livestock grazing that would harm monument objects, and that the BLM's proposed mitigation efforts were inadequate to address those harms. Wilderness Soc'y v. U.S. Bureau of Land Mgmt., 822 F. Supp. 2d 933 (D. Ariz. 2011). Critically, both monument management plans were approved in 2008, before Congress enacted the Omnibus Public Lands Act of 2009, which specifically directed the BLM to protect monument values. Monument planning also occurred before the BLM released Manual 6220 with its elucidation of the Act's direction to prioritize protection of monument values over competing uses. Absent this direction, the BLM arguably had greater discretion in balancing FLPMA's multiple use mandate with direction contained in the monument proclamations, and the court understandably deferred to the BLM's expert judgement. However, even when faced with less direction to protect monument values, the BLM's management plans still made "unavailable approximately 34,000 acres in Parashant that were previously available for grazing... and establish new standards and management actions to protect rangeland health." Id. at 938. The plans also did not open any new routes to motor vehicle use. Such management actions supported the court's conclusion that the BLM's plans fulfilled its 
The Arizona court relied heavily on In re Montana Wilderness Ass'n, 807 F. Supp. 2d 990 (D. Mont. 2011), which involved consolidated challenges to the BLM's management plan for the Upper Missouri River Breaks National Monument. Plaintiffs in that case challenged restrictions applied to river segments that were part of the National Wild and Scenic River System and to grazing management, claiming that both decisions failed to adequately protect monument resources. As with the challenge to plans for the Grand Canyon--Parashant and Vermillion Cliffs National Monuments, the plan at issue in Montana Wilderness predated both the Omnibus Public Lands Act of 2009 and BLM Manual 6220.

While the monument protections in Montana Wilderness may not have been as stringent as the plaintiffs hoped, the BLM's management plan closed 146 miles of the Upper Missouri National Wild and Scenic River to jet ski and float plane use, closed four of ten backcountry airstrips, restricted drilling natural gas wells on existing leases, imposed more stringent requirements on livestock grazing permits and leases, and permanently closed 201 of 605 miles of roads while imposing seasonal closures on another 120 miles of roads within the monument. 807 F. Supp. 2d. at 994 . Compared to the other five alternatives, the selected alternative "placed more restrictions on motorized use than every other alternative except Alternative $E$, closed more roads than Alternatives $A$, B, and $\mathrm{C}$, closed the same or more backcountry airstrips than every other alternative except Alternative $\mathrm{E}$, and imposed more restrictions on oil and gas operations than Alternatives A, B, and C." Id. at n.3. In light of these restrictions, and the lack of express statutory direction to elevate monument value protection over other uses, the district court had no trouble concluding that the BLM was within its discretion in balancing uses set forth in the proclamation; and the court of appeals agreed. Montana Wilderness Ass'n v. Connell, 725 F.3d 988 (9th Cir. 2013).

Western Watersheds Project v. Abbey, 719 F.3d 1035 (9th Cir. 2013), arose out of the same district court opinion but involved different appellants and focused on livestock grazing. Appellants contended that the BLM erred in incorporating livestock grazing standards that they believed were inadequate to protect monument objects or values. In the only decision to even mention the BLM's obligations under the Omnibus Public Lands Act or the NLCS, the court concluded without analysis or explanation that the grazing standards relied upon for the monument management plan were not in "conflict" with the NLCS's intent to "conserve, protect, and restore nationally significant landscapes." Id. at 1044. The court did not address any other aspect of the NLCS or the direction contained in the Omnibus Public Lands Act. That the court mentioned the NLCS at all is somewhat odd, given that monument planning was completed before the Omnibus Public Lands Act was enacted and the court declined to address guidance contained in the BLM Manual because it was issued after the plan was complete. Id. at n.4.

The final case about monument management involved the Sonoran Desert National Monument, which was proclaimed in 2001. National Trust for Historic Preservation v. Suazo, No. CV-13-01973-PHX-DGC, 2015 WL 1432632, at *1 (D. Ariz. Mar. 27, 2015). Although the BLM began monument planning a year later, it did not publish its draft management plan until 2011. Planning took an inordinately long time because the BLM faced a thorny problem involving recreational shooting within the monument. Existing regulations prohibiting the willful defacement, disturbance, removal, or destruction of sensitive objects and resources within the monument had been insufficient in protecting these resources. Id. at * 6 . The BLM therefore commissioned a study to better understand the scope and impact of recreational shooting, and to identify management options prior to preparing their monument management plan. The expert report recommended closing the monument to shooting in order to protect visitor safety and reduce ongoing damage to monument objects. This damage was described as "extreme" at sixteen sites within the monument. Id. at * 2 .

The BLM adopted the shooting ban recommendation in its draft plan and EIS. But while the final EIS was at the printer, the Department of the Interior ordered the BLM to keep the monument open to shooting and the BLM changed its decision without revising its analysis. The final decision was therefore diametrically opposed to the BLM's own analysis and challenged by plaintiffs because it would lead to irreversible damage to the wildlife and artifacts in the monument. Id. at *1.

The court began its review by recognizing that the BLM must manage the monument in compliance with the terms of the monument proclamation. While the court concluded that the proclamation did not require the BLM to select the most protective management option, the BLM was required to balance the "'paramount' purpose of protecting Monument objects with other purposes and needs, such as allowing recreational activities in the Monument." Though deference was due the BLM's decision in balancing competing uses, there was "simply too great an incongruity between the information contained in the Final EIS and the decision to allow shooting throughout the Monument." Id. at *7.

As the court noted, changes to the management plan were driven not by analysis, but in response to lobbying pressure from the National Rifle Association and other supporters of recreational shooting. Id. at * 8 . The court therefore distinguished the BLM's actions at the Sonoran Desert National Monument from the cases discussed above by noting that in each case, the BLM had taken at least some concrete steps to protect monument objects. While the management plan predated the BLM Manual 6220 and the court opinion does not mention the NLCS or Omnibus Public Lands Act, those authorities appear to support the plaintiffs' position and the court's ruling, had the court needed to reach that argument.

While these cases highlight the deference courts will give to the BLM's weighing of management options, they are all distinguishable from the GSENM and BENM plans in at least two important respects. First, in all but Suazo, the BLM's preferred alternative increased protection for monument objects and values--and in Suazo, reduced protections that were based on political pressure proved to be the plan's Achilles heel. At the GSENM and BENM, the agencies proposed management reflects the least protective action alternative, and in many cases, a reduction in protections from the status quo. And as litigants contend, scant protections reflect a policy choice to elevate energy development above other uses.

Second, all these cases predated publication of BLM Manual 6220, and the monument management plan in Suazo was the only one to be completed after Congress enacted the Omnibus Public Lands Act. However, notwithstanding the Act's explicit directive to the 
BLM to elevate protection of values identified in monument proclamations over other uses, Suazo failed to analyze any obligations associated with inclusion in the NLCS. Explicit requirements to protect monument resources have increased since these cases were resolved and the adequacy of the GSENM and BENM management plans must be measured against the current higher standard.

Measuring Impacts against the Proper Baseline

The agencies' baseline for its NEPA analysis raises an additional question. The comparison of alternatives "is the heart of the environmental impact statement... present[ing] the environmental impacts of the proposal and the alternatives in comparative form, thus sharply defining the issues and providing a clear basis for choice among options." 40 C.F.R. [section] 1502.14. The no action alternative is critical, providing a "benchmark, enabling decision makers to compare the magnitude of environmental effects of the action alternatives." Forty Most Asked Questions Concerning CEQ's National Environmental Policy Act Regulations, 46 Fed. Reg. 18,026, 18,027 (Mar. 23, 1981). The no action alternative must accurately state what could occur but for agency action, and agencies can neither base the no action alternative on documents that have been invalidated by a court, Friends of Yosemite Valley v. Kempthorne, 520 F.3d 1024, 1038 (9th Cir. 2008), nor ignore binding legal requirements. Oregon Natural Resources Council Action v. U.S. Forest Service, 445 F.Supp.2d 1211 (D. Or. 2006).

For both the GSENM and BENM, the BLM failed to address the limitations imposed by the NLCS, section 302(a) of FLPMA, and BLM Manual 6220 when it formulated its no action alternative. By ignoring the legal requirement to protect monument resources, the BLM overstates the level of impact that could occur under the no action alternative.

Inflated baseline impacts also make the impacts that would occur from implementing any of the action alternatives appear less significant than they may actually be. These are important concerns because the agencies repeatedly state that at least with respect to the BENM, all action alternatives would have less potential for surface disturbance and therefore less potential to impact monument resources than the no action alternative. See, e.g., BENM Proposed Plan at 3-9. They also state that all action alternatives would include more provisions addressing the proper care and management of monument objects and values than the no action alternative. Id. at 3-21. Even if these suspect claims are taken as true, they overlook that the action alternatives are more protective primarily because the BLM failed to prioritize protection of monument objects in its no action alternatives.

\section{The Future of Monument Management}

We can only speculate whether the cases addressing national monument management would have turned out differently had Congress formally protected monuments as part of the NLCS earlier, or if the BLM had released Manual 6220 before beginning monument planning. What is clear, however, is that Congress raised the bar for protecting monument values since the cases discussed above were decided. It is also clear that the GSENM and BENM were reduced following aggressive lobbying by energy development interests. While a federal court will almost certainly be called upon to determine whether energy dominance can be adequately reconciled with monument protection, the Trump Administration does not appear to be setting itself up for success.

The administration's approach to monument planning may prove to be all for naught if legal challenges to monument reductions succeed. If that occurs, the existing plan for original GSENM would likely be reinstated, at least until a new plan can be prepared. The BLM and Forest Service would also need to start planning for BENM afresh to address the entire 1.35-million-acre monument area. Such action would almost certainly push planning out past the 2020 election and that, of course, could result in a changed administrative policy focus.

The Trump Administration could decide to change its approach to monument planning and adopt alternatives that are more in line with statutory protections afforded National Conservation Lands in the final management plans. This may be the administration's best option because even if it chooses to remain focused on resource extraction elsewhere on the public lands, the drive for energy dominance within national monuments is likely to spawn more litigation than development.

Alternatively, the administration may double-down on development and proceed with management plans that minimize burdens on energy development and extractive industries. They may also choose to emphasize active management within national monuments. That would almost certainly lead to more litigation, and litigation would delay plan implementation until after the 2020 election.

More troubling though is the prospect of monument managers continuing to operate without clear direction and with inadequate resources. Almost three years have passed since President Obama designated the BENM and still not a single sign has been installed, no interpretive displays have been built, and the only visitor center is in a renovated bar operated not by the federal government but by a local nonprofit organization. We don't think that is what Congress had in mind when it told the Secretary of the Interior to "conserve, protect, and restore nationally significant landscapes that have outstanding cultural, ecological, and scientific values for the benefit of current and future generations." America's national monuments deserve better.

Mr. Ruple is a professor of law (research) and Wallace Stegner Center Fellow at the University of Utah's S.J. Quinney College of Law. He volunteers on the Board of Directors for Friends of Cedar Mesa, which is challenging reductions to the Bears Ears National Monument. He may be reached at john.ruple@law.utah.edu. Ms. Tanana is a research associate and Wallace Stegner Center Fellow at the University of Utah's S.J. Quinney College of Law. She is also an associate faculty member at Johns Hopkins University's Bloomberg School of Public Health. She may be reached at heather.tanana@law.utah.edu.

Please Note: Illustration(s) are not available due to copyright restrictions. 
Source Citation (MLA 8th Edition)

Ruple, John C., and Heather Tanana. "Beyond the Antiquities Act: Can the BLM Reconcile Energy Dominance and National Monument Protection?" Natural Resources \& Environment, vol. 34, no. 3, Wntr 2020, p. 8+. Gale OneFile: Environmental Studies and Policy, https://link-gale-

com.ezproxy.lib.utah.edu/apps/doc/A616315263/PPES?u=marriottlibrary\&sid=PPES\&xid=902b66c7. Accessed 21 July 2020.

Gale Document Number: GALE|A616315263 